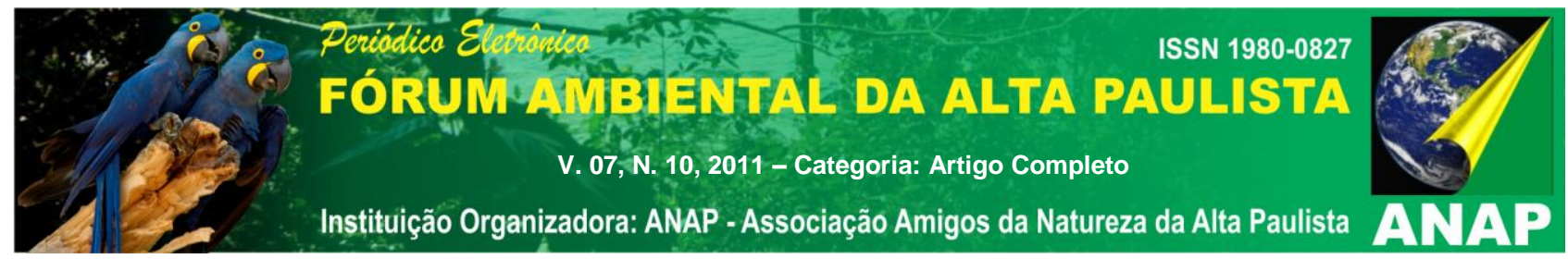

\title{
O COLONO E O ÍNDIO NA OCUPAÇÃO DA NOVA ALTA PAULISTA.
}

\section{Carlos Vitório Martins Joviano ${ }^{1}$}

Resumo: O processo de produção e ocupação do território da Nova Alta Paulista, teve como ponto de partida a análise do avanço das frentes de expansão representada por posseiros e proprietários, que avançaram em direção a oeste, praticando a agricultura de subsistência e posteriormente, pelas Companhias Colonizadoras e compradores de terras vindos das áreas antigas de plantação de café, que abriram espaço para a ocupação baseado numa ação conjunta formada por três aspectos violentos: a grilagem de terras devolutas com a falsificação de documentos em cartórios e sua posterior comercialização; o aniquilamento das populações indígenas que habitavam a região antes da chegada dos compradores de terras marcada por conflitos violentos entre a frente de expansão inicial e os grandes proprietários de terras (lícitas ou ilícitas) organizados em Companhias Colonizadoras impulsionadas pela grande quantidade de terras férteis que havia no espigão entre o rio do Peixe e o Aguapeí para comercialização e plantação da cultura de café entremeada com produtos de subsistência.

Palavras chave: Ocupação; frentes de expansão; violência; indígenas; companhias colonizadoras.

\section{Introdução}

Desde o princípio do século XIX, latifundiários e posseiros concorrem a uma parcela de chão, num jogo de força que mostram interpretações diferentes sobre o direito à terra. Assim estes ditos proprietários buscam proteger o que consideram direito de propriedade fazer ser lícito o que é ilícito, isto é, busca validar sua ocupação ilegal numa posse territorial legal, já que a luta pela terra delegava, além de possibilitar o domínio

\footnotetext{
${ }^{1}$ Mestre em Geografia pela UFGD

Docente dos cursos de Pedagogia e Ciências Biológicas da UNIFADRA,

Rua dos Pinheiros, 395, Jardim das Palmeiras, CEP 17900-000 - Dracena - SP.

carlosjoviano@hotmail.com
} 


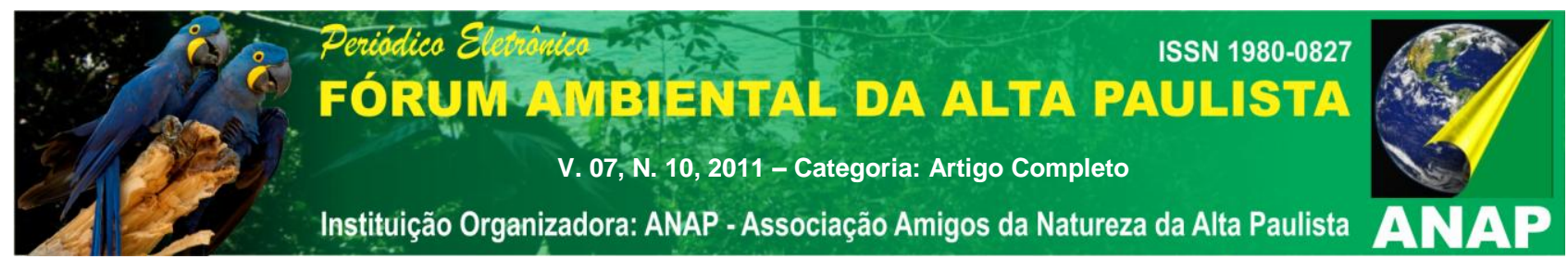

sobre a mesma, também o comando sobre os indivíduos que ali viviam ou almejavam residir. Por isso, segundo Motta (2001), em alguns locais, a derrubada de uma cerca e sua construção em outro lugar representava a ampliação de uma área que, com o tempo, se transformava em mais terras usurpadas.

Ratificando todas estas manobras, era comum notar que as articulações políticas de alguns grandes grileiros se legitimaram devido a proteção que estes encontraram diante de intelectuais como, cartorários, advogados, magistrados e delegados que como os primeiros, viam essa forma de acesso a terra, como um caminho de se atingir o desenvolvimento e não como uma forma de violência a legalidade. Assim sendo, nesse processo de apropriação indiscriminada de terras devolutas na região da Nova Alta Paulista, fazendeiros, grandes grileiros e empresas imobiliárias pressionavam o Estado para que, com isso, obtivessem apoio de parte da sociedade política e assim justificassem a reprodução de suas práticas ilegais, confundindo dessa forma os interesses dos grandes grileiros e proprietários com o interesse da sociedade civil.

Esta situação de comprometimento entre a ilegalidade das ocupações e o apoio de parte da sociedade política, alegando necessidade de desenvolvimento da região foi assim descrito por Viana (1933):

Nessa obra de conquista civilizatória da terra, o bugreiro vence o obstáculo material, que é o índio nômade, povoador infecundo da floresta infecunda. (...) outro obstáculo jurídico, que é o direito de propriedade (...). É ao grileiro que cabe resolver esta dificuldade. É ele que vai dar ao colonizador progressivo, cheio de ambições e de capitais, o direito de explorar este tesouro infecundo. Para isso cria, (...) pela falsidade, o indispensável título de propriedade. $\mathrm{O}$ bandeirante antigo, predador de índios (...) faz-se bugreiro insidioso, eliminador do íncola inútil, e grileiro solerte, salteador de latifúndios improdutivos. Exerceram ambos, porém, duas funções essenciais à nossa obra de expansão colonizadora, (VIANNA, 1933, p.97 e 98). 


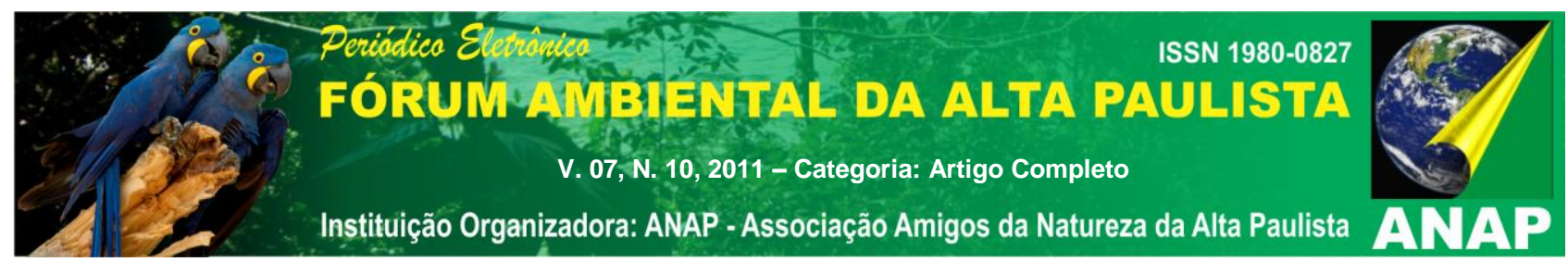

Deste modo, as terras da Nova Alta Paulista foram negociadas e até barganhadas entre os grandes grileiros que passaram a dominar uma região de florestas virgens habitadas por povos indígenas. Todavia, no entender destes proprietários a apropriação ilícita das terras estaria vinculada ao processo de civilização idealizado no Brasil a partir do final do século XIX e início do século XX, que justificou o avanço das fazendas de café sobre as florestas do oeste e em consequência sobre o território que por hora era ocupado por grupos indígenas.

A Nova Alta Paulista ${ }^{2}$, para efeito de localização, é considerada o extremo oeste de uma região ferroviária ${ }^{3}$, circunscrita na porção ocidental do Estado de São Paulo, entre o Rio Aguapeí ao norte e o Rio do Peixe, ao sul, por onde passa o traçado final do tronco oeste da Companhia Paulista de Estradas de Ferro (atual Ferroban).

Estendendo-se por aproximadamente 190 quilômetros de comprimento no sentido leste - oeste, e 65 quilômetros de largura no sentido norte - sul, a Nova Alta Paulista forma um espigão de relevo planáltico com pequenas ondulações e altitudes médias oscilando entre 276 metros em Panorama (barrancas do rio Paraná) e 486 metros em Parapuã (leste), paisagem geológica própria dos planaltos e chapadas da borda leste da bacia do rio Paraná (Planalto Ocidental Paulista), coberto por solos erodidos do tipo latossolo fase arenosa e podzolizado, com média fertilidade.

\footnotetext{
${ }^{2}$ Segundo a Geógrafa Izabel C. Gil, é uma sub-região composta por 24 municípios que recebe este nome por ser a última região do Estado a ser colonizada, por isso "Nova", além de ter uma "alta" quilometragem das antigas áreas de plantação de café, e "Paulista" derivado do nome da ferrovia, Cia Paulista de Estrada de Ferro, que cortou este trecho até o rio Paraná (Revista NERA, 2004).

${ }^{3}$ O oeste do Estado de São Paulo foi popularmente regionalizado com os nomes dos trechos das ferrovias e esta região ferroviária citada é denominada Alta Paulista e possuem aproximadamente 65 quilômetros de largura no sentido norte - sul e 250 quilômetros de comprimento no sentido leste - oeste, indo do município de Garça a leste até o município de Panorama a oeste.
} 


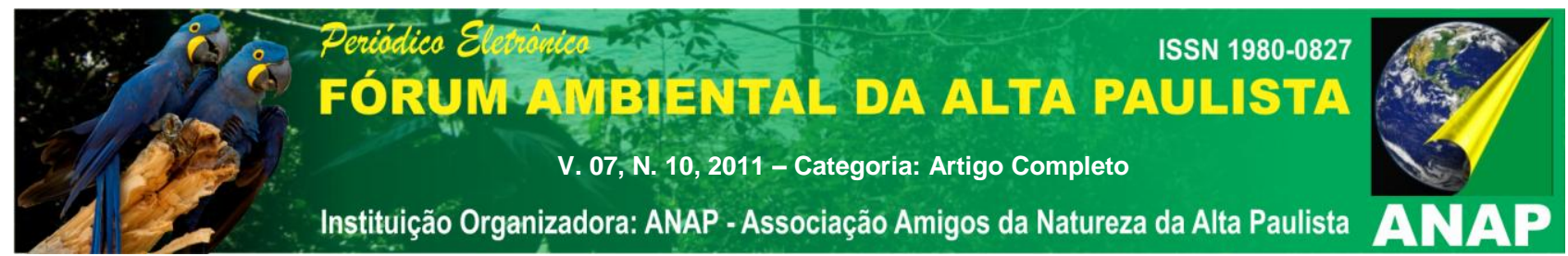

No que se refere ao clima, verifica-se a existência de duas estações bem definidas: uma estação mais quente e úmida, com chuvas abundantes no verão e outra estação seca, com tempo estável no inverno, classificado segundo Monteiro (1973) como climas tropicais alternadamente secos e úmidos. A pluviosidade oscila entre $1400 \mathrm{~mm}$ e 1600 mm, o que propicia a formação de uma cobertura florestal denominada mata tropical pluvial, com aspecto de mata fechada, hoje praticamente extinta na região devido o desmatamento, restando somente alguns minúsculos capões isolados e pequenas faixas nas proximidades dos alguns córregos e rios.

1. Região da Nova Alta Paulista no Estado de São Paulo

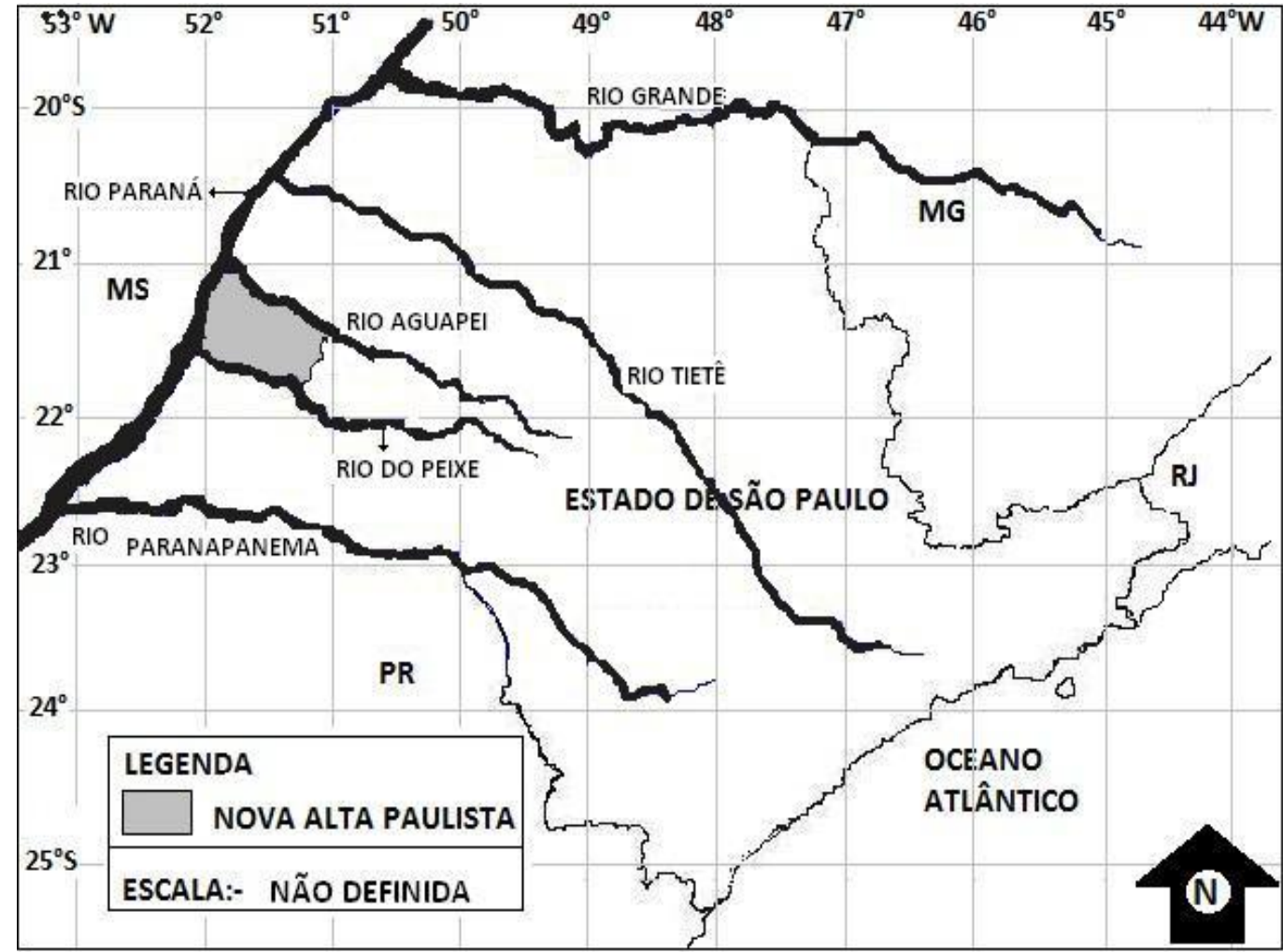

FONTE: Secretaria Municipal de Assuntos Viários de Dracena - 2009

Organização e adaptação: Joviano, C. V. M. 


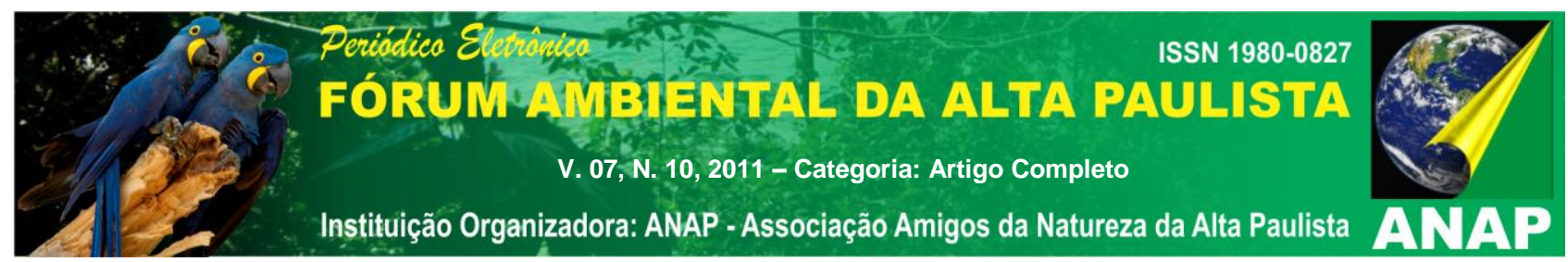

Segundo Leonídio (2007), a biografia da ocupação regional do extremo oeste paulista e em consequência da Nova Alta Paulista, a partir de meados do século XIX até meados do século XX é conduzida por uma cadeia de operações ilegais, invasões de terras e falsificação de títulos de propriedade, envolvendo grandes proprietários de terras de nomes conhecidos na região, até pequenos camponeses posseiros. Este fato teve sua gênese caracterizada por uma ação conjunta de três aspectos violentos: a grilagem de terras e sua posterior comercialização; o aniquilamento das populações indígenas e a destruição do ambiente natural. Esse processo pode ser identificado na atualidade devido à herança deixada nos intensos conflitos pela posse e legalização de lotes de terras, pela quase ausência da população nativa e pela exígua paisagem natural atual que resta das florestas fechadas de outrora.

Este ambiente de medo gerado pelas agitações na posse da terra, não foi exclusivo apenas dos conflitos entre grandes grileiros e fazendeiros contra os pequenos proprietários e posseiros, pois um dos mais sangrentos capítulos da História paulista, o massacre dos índios Kaingang no extremo oeste do Estado até hoje não teve um estudos compatível com sua importância.

Muito antes de se estabelecer estes personagens que provocaram tal estado de conflito por terras no Oeste Paulista, os índios Kaingang já haviam experimentado a amarga chegada das relações mercantis em suas terras. Já que no Estado de São Paulo a ocupação se dava através do avanço para o oeste, em terras consideradas pela cultura da época como selvagens e desocupadas. 


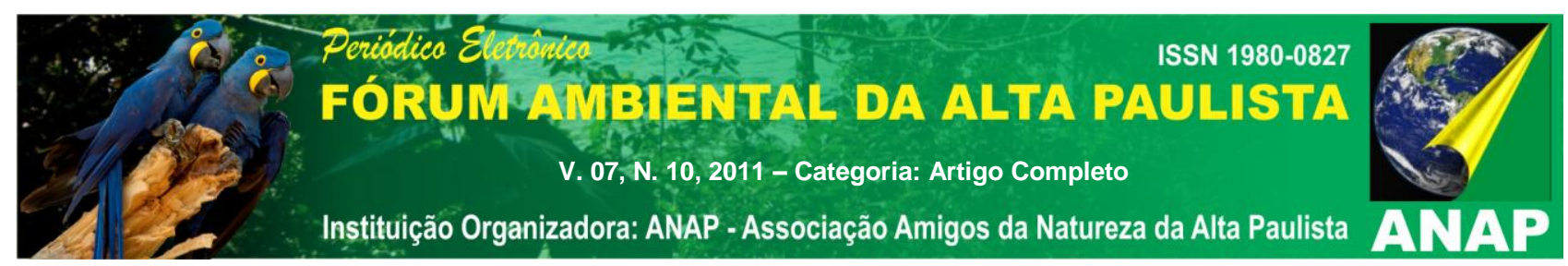

Em São Paulo, a ocupação Kaingang se estendia pelo quadrilátero, que vai da região de Bauru ao rio Paraná e do Rio Tietê ao Rio Paranapanema, conforme o mapa a seguir:

Localização dos índios Kaingang no Estado de São Paulo

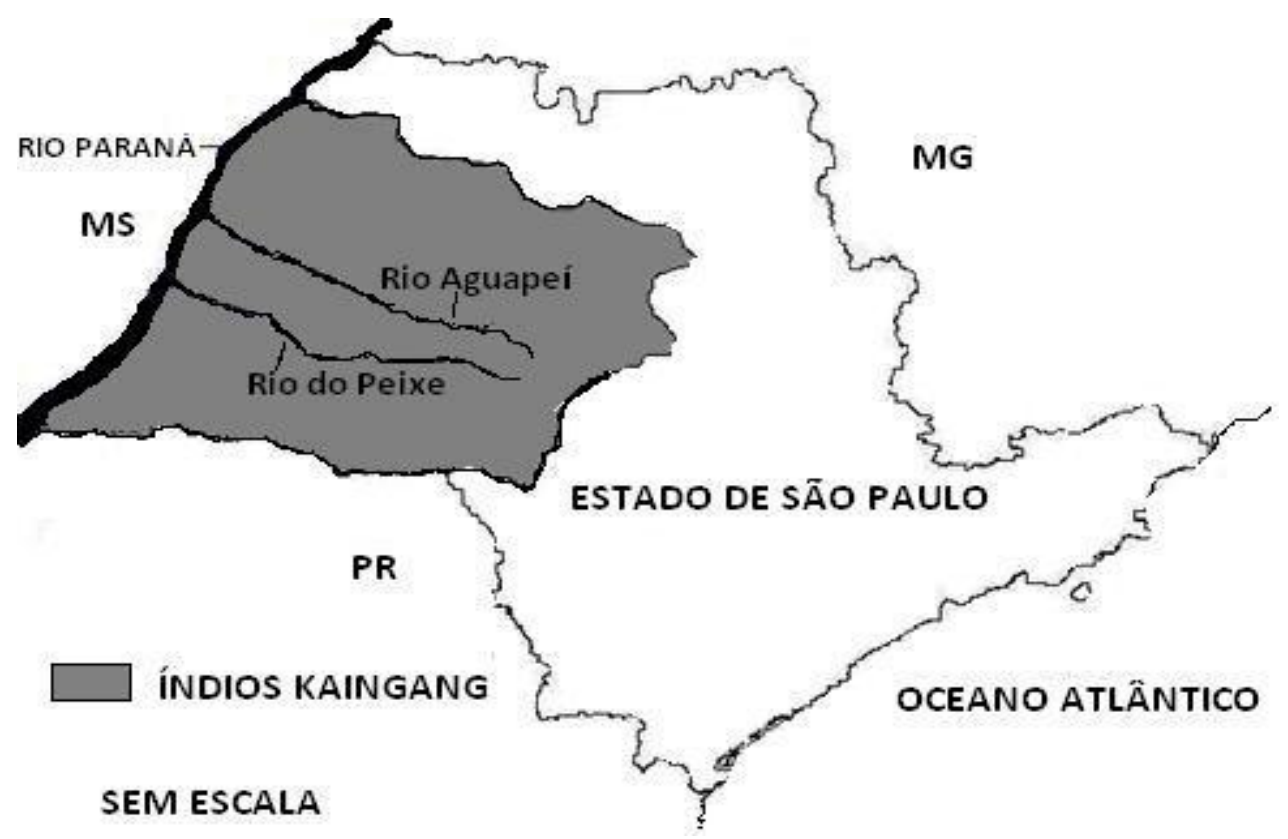

Fonte: Atlas Geográfico Paulista - 1976

Organização: Joviano, C.V.M.

Como resultado do avanço desse processo, houve quase quatro mil índios dizimados, em pouco mais de uma década, com consumação de atrocidade muito semelhante aos requintes do holocausto, devido aos contatos truculentos e sempre sangrentos entre índios e "pioneiros", na passagem do século XIX para o século XX. 


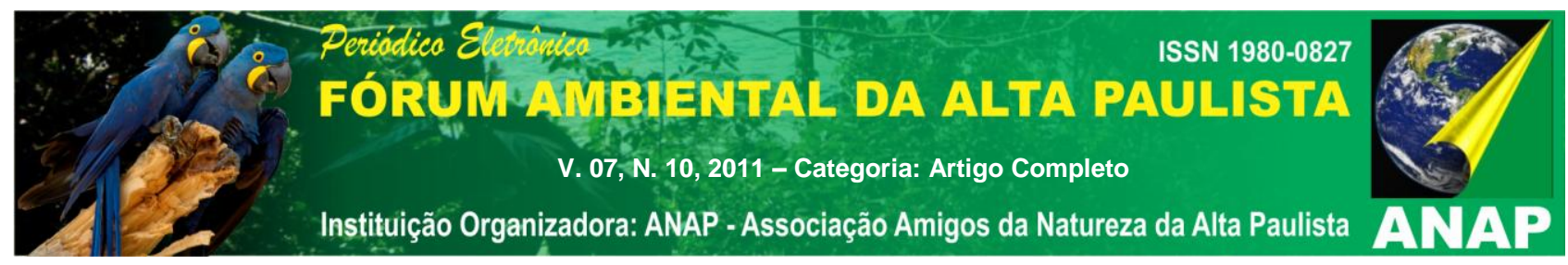

A incursão no território Kaingang começou por volta de 1895, de maneira ainda tímida, mas sempre caracterizada pela ação truculenta dos bugreiros ${ }^{4}$, que agiam inicialmente a mando de grileiros que se aventuravam no espigão entre os rios do Peixe e Aguapeí, onde loteavam e vendiam ilegalmente terras devolutas. As atrocidades cometidas contra os Kaingang e as transações ilegais terras deram, portanto, o tom do início da ocupação deste vasto território.

O povo Kaingang foi alvo da marcha capitalista que abriu e expandiu uma nova fronteira agrícola, impulsionada pela expansão do café e acelerada pela construção da ferrovia da Cia Paulista de Estrada de Ferro, rumo ao Estado de Mato Grosso. Diante de tal situação, os Kaingang eram considerados um entrave para as estratégias expansionistas da ferrovia e também para as rentáveis (e ilícitas) transações de terras.

Neste contexto, para Leonídio (2007), não era por acaso o uso dos termos linguísticos "desbravar" e "sertão desconhecido" pelos "sertanejos" que por estas terras se aventuravam, já que para ele, o termo desbravar tem "pelo menos três sentidos primordiais e interconexos: livrar de obstruções, de obstáculos, como anteriormente em relação à Lei de Terras; fazer perder a braveza, amansar; tornar civilizado." (LEONÍDIO, 2007, p. 4). Além disso, o autor, na mesma página, descreve estes desbravadores como sendo "homens práticos do sertão", conhecidos como "picadeiros", termo da linguagem regional brasileira que significa "abridores de atalho na mata a golpes de facão ou de foice". Daí se verificar que o assunto era extremamente complexo e que de alguma forma, na época, era usado para justificar a matança, pois para Leonídio:

\footnotetext{
${ }^{4}$ Termo que se origina da palavra bugre, pelo qual ficaram conhecidos os indivíduos especializados em atacar e exterminar indígenas, também prestava serviços de proteção a viajantes, tropeiros e agrimensores quando necessitavam atravessar ou permanecer em territórios onde a presença indígena era freqüente.
} 


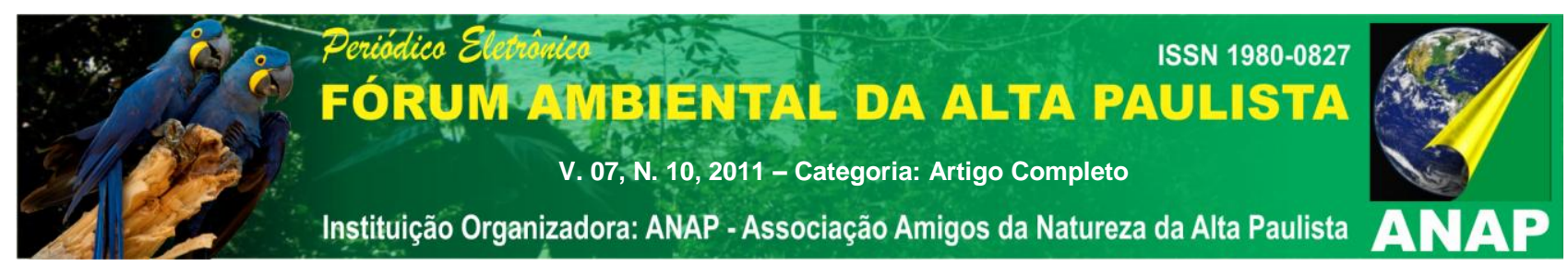

(...) se por um lado o extermínio de índios por invasores e grileiros de terras é uma realidade incontestável, não é menos real o clima de tensão e medo constantes em que viviam aqueles que se estabeleciam nestes lugares, fossem eles latifundiários ou pequenos sitiantes. (LEONÍDIO, 2007, p. 5)

Por isso, alguns autores da primeira metade do século $X X^{5}$, como Cobra (1923), Giovannetti (1943), Monbeig (1949), quando tratavam do assunto, muitas vezes se preocupavam mais em descrever em suas pesquisas, como os sertanejos se defendiam dos ataques dos índios ferozes e como estes atrapalhavam o avanço das frentes de expansão, do que, em evidenciar as questões relativas às invasões brancas nas terras indígenas. Contudo, revela-se uma contradição na própria obra notada em Cobra (1923), quando afirma que "quando saíam de casa para o trabalho era mister levar consigo a mulher, os filhos, os animais domésticos, os objetos de uso e tudo enfim, para subtrair aqueles ao massacre" (COBRA, 1923, p. 51).

Giovannetti (1943) segue o mesmo pensamento de Cobra quando afirma que "aconteceram lutas violentas entre bárbaros selvagens e os homens civilizados" (GIOVANNETTI, 1943, p.67, grifo nosso), considerando o indígena como um obstáculo ao avanço da marcha civilizatória. Ainda, no mesmo caminho Monbeig (1984) afirma:

Muito má foi a fama deixada pelos Kaingang. Sem armamento, com grandes arcos de pontas frequentemente revestida de ferro, asseguravam a supremacia como caçadores. [...] Ficavam os índios a espreita dos desbravadores aproveitando-se da desatenção destes para atacá-los, apoderar-se de suas armas e utensílios, carregando tudo que podiam encontrar em suas pobres casa. (MONBEIG, 1984, p. 130-131)

\footnotetext{
${ }^{5}$ Amador Nogueira Cobra (1923), Bruno Giovannetti (1943), Pierre Monbeig (1949).
} 


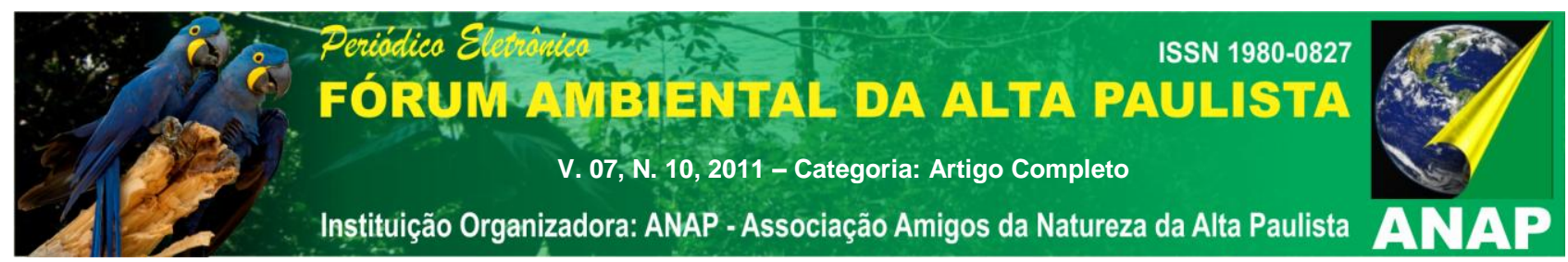

O amparo das forças públicas em âmbito estadual e a omissão do poder federal e da imprensa foi um golpe mortal para os Kaingang, pois desde a passagem do Império para a República, a Igreja estava apartada do processo de pacificação dos índios. O governo, por sua vez, não havia instituído organismos competentes para substituí-la neste encargo. Além disso, fez vistas grossas ao genocídio. Com capacidade de fogo imensamente maior do que o dos índios, que contavam somente com lanças, as frentes de conquista atropelaram os nativos como uma locomotiva desgovernada. Grupos de jagunços armados e "bugreiros" foram organizados - sendo "a época dos mais famosos bugreiros e das dadas ${ }^{6}$ mais sangrentas" (MONBEIG, 1984, p. 131) - com a finalidade de "varrer os índios das matas da margem direita do Paranapanema e de grande parte da bacia do rio do Peixe" (COBRA, 1923, p. 64).

Porém, a intensa rebeldia dos nativos tornou a violência ainda mais dramática, tendo como exemplo da barbaridade e da carnificina, o depoimento feito por Cobra (1923):

Em seguida, os sitiantes penetraram nas habitações e encontrando-se com as índias, a umas aprisionaram, a outras mataram, bem como aos indiozinhos, aos quais chegavam a levantar do chão ou da cama, atira-los para o ar e espetá-los em ponta de faca; outras vezes tomá-los pelos pés e dar com as suas cabecinhas nos paus, partindo-as. Às índias grávidas rasgava-lhes os ventres e depois de finda a carnificina, amontoavam os cadáveres sobre os quais lançavam fogo [...]. Deitavam substâncias venenosas nos utensílios de cozinha e nos alimentos ali guardados, para que fosse vitimado no comer algum que porventura sobrevivesse. Faziam prisioneiros mulheres e alguns rapazes para as fazendas, ficando como semi-escravizados. (COBRA, 1923, p. 143).

Todavia depois de persistente pressão de um grupo comandado por intelectuais, políticos e militares, o governo federal determinou em 1910, a criação do Serviço de Proteção ao Índio, que tinha a missão de evitar mais chacinas e apaziguar os Kaingang. Em 1911, enviou à região, um emissário da Comissão Rondon, com o propósito de

\footnotetext{
${ }^{6}$ Segundo Monbeig, (1884) eram expedições predatórias em território indígena organizadas com finalidade punitiva pelos bugreiros em resposta a algum ato violento cometido pelos indígenas a famílias de sertanejos.
} 


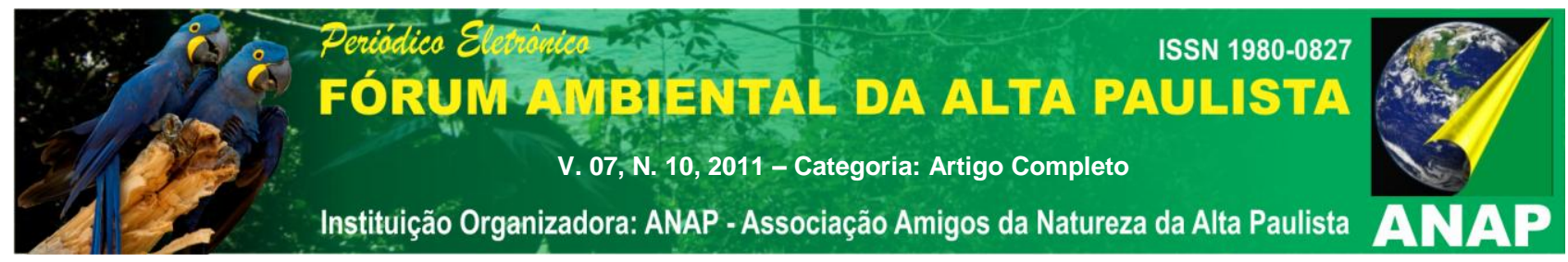

impedir uma "dada" e requerer a criação de uma área de proteção aos índios. Porém, já era tarde, pois do contingente estimado em quatro mil índios que habitavam o Oeste Paulista, restaram somente 700. Por isso, segundo Cobra (1923), o encarregado do Governo Federal “(...) permaneceu por pouco tempo no lugar, por não haver mais nada o que fazer: não encontrou mais índios para aldear" (COBRA, 1923, p. 145).

Dessa forma, sob o chefia do marechal Cândido Rondon, a base do SPI foi montada na região Noroeste do estado, localidade que naquela ocasião encontravam-se alguns grupos pequenos de Kaingang acuados pela ferrovia, restantes do extermínio. Porém, o contato inicial, só ocorreria após dois anos e a partir de então, a "pacificação" seria concretizada aos poucos.

Os poucos remanescentes continuaram sendo vitimados, por inimigos também impiedosos, como as enfermidades, a gripe espanhola e o sarampo, contra as quais não tinham imunidade. Por isso, em 1916, estavam reduzidos a 173 e em 1921 foram confinados em dois modestos aldeamentos, localizados em Tupã e Graúna.

\section{Considerações finais}

Este ambiente de disputa e medo criado pela eclosão dos conflitos de grilagem de terras entre grandes fazendeiros, pequenos proprietários e posseiros, além das pendências judiciais geradas entre estes e o Estado e vice versa, são fatos que marcaram a memória do povo do extremo oeste paulista. Mas o que se percebe é que quando se relata a história indígena Kaingang, pouco ou nada se recorda e ainda de uma forma negativa para a etnia indígena, pois se criou a imagem do índio como um dos maiores empecilhos para o avanço das atividades ditas "civilizatórias" na região, evidenciando a 


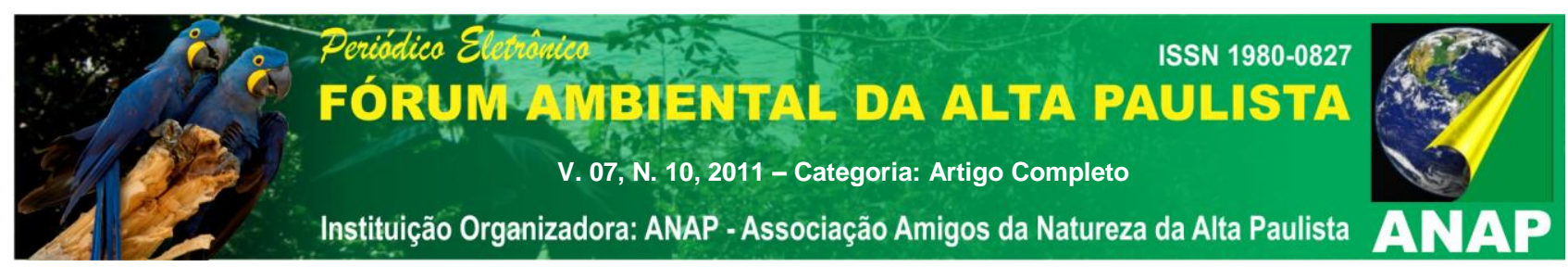

contraposição ideológica, que não considerou o genocídio indígena um crime, mas somente uma ação inevitável, praticada para abater uma barreira que se colocava entre o branco civilizado e a terra para empreendimento.

Hoje os poucos remanescentes Kaingang estão confinados em duas pequenas reservas, o que para este povo e suas tradições nômades, essas reservas representavam uma afronta.

\section{Referências Bibliográficas}

COBRA, Amador Nogueira. Em um recanto do sertão paulista. São Paulo: Hennies, 1923.

GIL, Izabel Castanha. Territorialidade e desenvolvimento contemporâneo, Revista NERA, ano 7, no 4,Presidente Prudente, 2004

GIOVANNETTI, B. Esboço histórico da Alta Sorocabana. São Paulo, Empresa Gráfica da revista Tribunais, 1943.

LEONÍDIO, Adalmir. Matar e desmatar. A ocupação inicial do Pontal do Paranapanema (1850-1930), XXIV Simpósio nacional de História - 2007

MONBEIG, Pierre. Pioneiros e Fazendeiros de São Paulo, 2ª edição traduzida, Hucitec editora Polis Editora. 1984

MONTEIRO, C. A. de F. A dinâmica climática e as chuvas do Estado de São Paulo. Estudo em forma de Atlas. São Paulo. IGEOG / USP, 1973

MOTTA, Márcia; PINEIRO, Theo Lobarinhas. Voluntariado e universo rural: A grilagem como legado. Rio de Janeiro, Vício de Leitura, 2001

VIANNA, Oliveira. Evolução do povo brasileiro. $2^{a}$ ed. São Paulo, Companhia Editora Nacional, 1933 